\title{
TEMPORAL ARBITRARINESS: A BACK TO THE FUTURE LOOK AT A TWENTY-FIVE-YEAR-OLD DEATH PENALTY TRIAL
}

\author{
Mary Kelly Tate*
}

\section{INTRODUCTION}

This symposium essay is a thought experiment-a "back to the future" re-imagining of the capital murder trial of Tommy David Strickler, an indigent man deemed borderline mentally retarded. ${ }^{1}$ In 1990, Strickler was convicted and sentenced to death for the robbery, abduction, and murder of a young African American woman. $^{2}$ On July 21, 1999, Strickler became the sixty-eighth person executed in Virginia in the death penalty's modern era. ${ }^{3}$

In post-conviction habeas corpus proceedings, Strickler came uncommonly close to judicial relief when the Supreme Court of the United States agreed to review the prosecution's failure to

* Associate Clinical Professor of Law, Director of Institute for Actual Innocence. J.D., 1991, University of Virginia. I thank Professor Corinna Barrett Lain, my dear friend and colleague, for her generous spirit and invaluable assistance during the writing process. I also extend my appreciation to my research assistant Zachary MacDonald for his able research and editing support.

1. See Strickler v. Greene, 57 F. Supp. 2d 313, 318 (E.D. Va. 1999) (granting Strickler's counsel's application for lawyer's fees in post-conviction clemency proceedings in recognition of Strickler's indigent status); see also Ian Record, Strickler Gets Death Sentence, BREEZE, Sept. 20, 1990, at 2 ("Strickler has an IQ of 74, Warren testified. People with IQs of 70 can be considered mentally retarded, she said.").

2. See Strickler v. Greene, 527 U.S. 263, 266 (1999).

3. Searchable Execution Database, DeATH PENALTY INFO. CTR., http://www.deathpe naltyinfo.org/views-executions?exec_name_1=\&sex=All\&state $\% 5 \mathrm{~B} \% 5 \mathrm{D}=\mathrm{VA} \&$ sex_1=All\& federal=All\&foreigner=All\&juvenile=All\&volunteer=All (last visited Feb. 27, 2015) (listing Strickler as the sixty-eighth person executed in Virginia since 1976). Furman v. Georgia is a 1972 Supreme Court decision holding, through a fractured plurality opinion, that arbitrariness in imposing the death penalty rendered it unconstitutional in violation of the Eighth and Fourteenth Amendments. 408 U.S. 238, 240 (1972) (Douglas, J., concurring); id. at 295 (Brennan, J., concurring). In 1976, the Supreme Court overturned its Furman decision with Gregg v. Georgia, holding that new statutory schemes adding procedures for courts and juries in applying the death penalty limited its arbitrariness, which made it permissible under the Eighth and Fourteenth Amendments. 428 U.S. 153, 169, 204-07 (1976). Accordingly, the "modern era" refers to cases decided after the Supreme Court's decision in Gregg v. Georgia. 
provide exculpatory statements from its star witness. ${ }^{4}$ Within the fractured forty-four-page opinion, the Court concluded that the statements in question, although exculpatory as a matter of law due to their contradiction of trial testimony, would not have altered the outcome of Strickler's trial if the defense had possessed them during trial preparation, cross-examination, opening and closing statements, and sentencing. ${ }^{5}$ Thirty-four days later, Strickler was executed. ${ }^{6}$

I wonder how Strickler's Augusta County, Virginia trial would have been different had it happened today. How does the circumstance of time affect capital defendants? And what might that say about the stability of our notions of justice when it comes to our most severe, irreversible punishment? I pose these questions because I was one of Strickler's federal habeas corpus counsel in the 1990s.

To illustrate the role of the temporal in capital trial outcomes, I use Strickler's trial, specifically its core narrative, as a case study. It affords us a glimpse into many of the structural hallmarks and pitfalls of capital litigation in twentieth-century America. Other than the human suffering for the victim's family, the community, and Strickler himself, Strickler's trial is prosaic in many of its cultural characteristics. A tragic and senseless murder, an indigent defendant with cognitive vulnerabilities, an ambitious pro-death penalty prosecutor, and a rural setting are all in play. Its one feature that deviates from the prototypical capital case is its racial contours. The defendant was white and the victim was black; usually those features run the other way. ${ }^{7}$ This inversion is likely explained by socioeconomic factors. As the death penalty's history demonstrates, the identity of the victim

4. See Strickler, 527 U.S. at 265-66.

5. Id. at 293-96.

6. Compare id. at 263 (decided June 17, 1999), with Thomas Strickler, DEATH PENALTY INFO. CTR., http://deathpenaltyinfo.org/thomas-strickler (last visited Feb. 27, 2015) (indicating Strickler was executed on July 21, 1999).

7. Strickler, 527 U.S. at 266 (indicating Leanne Whitlock was African American); Thomas Strickler, supra note 6 (indicating Strickler was white); see Searchable Execution Database, DEATH PENALTY INFO. CTR., http://www.deathpenaltyinfo.org/views-executions? exec_name_1=\&race $\% 5 \mathrm{~B} \% 5 \mathrm{D}=$ White\&sex $=m \&$ state $\% 5 \mathrm{~B} \% 5 \mathrm{D}=\mathrm{VA} \& \mathrm{race} \_1 \% 5 \mathrm{~B} \% 5 \mathrm{D}=\mathrm{Black}$ \&sex_1=f\&federal=All\&foreigner=All\&juvenile=All\&volunteer=All (last visited Feb. 27, 2015) (demonstrating that only four white men have been executed for the murder of only black victims in Virginia). 
itness. ${ }^{4}$ Within the soncluded that the as a matter of law would not have alznse had possessed ition, opening and $r$-four days later,

irginia trial would w does the circumhat might that say en it comes to our hese questions bepus counsel in the

al trial outcomes, I rative, as a case ie structural halltwentieth-century he victim's family, r's trial is prosaic gic and senseless vulnerabilities, an rural setting are e prototypical capvas white and the e other way. ${ }^{7}$ This c factors. As the atity of the victim

matters in terms of when the penalty is deployed and here the victim was an upwardly mobile college student full of promise. ${ }^{8}$

On the whole, the Strickler case is a fitting specimen to examine how time intersects with the death penalty as an institution. My aim is focused mostly on how the trial narrative would have been altered in today's doctrinal, capital defense, and normative environments. I train my sight on the "story" to understand the role of the temporal in capital litigation because narrative is where capital trials rise or fall. Narrative, as shaped through adversarial engagement with evidence, is the essential determinant during plea-bargaining, the guilt or innocence phase, and the sentencing phase of capital trials. ${ }^{9}$ Capital litigation lawyers and post-conviction lawyers know it is the "story" that drives outcomes. ${ }^{10}$ The story of the case was at the heart of Strickler's postconviction efforts and at the heart of Strickler's capital murder trial.

The body of this essay is divided into three parts. Part I is a narrative summary of the case with factual and procedural highlights. Part II situates the case in the temporal space in which it occurred by addressing three structural realities-death penalty jurisprudence, improved capital defense in Virginia, and deep cultural shifts concerning the criminal justice system's fallibility and the death penalty's legitimacy and role-which are substantially different today than they were at the time of Strickler's trial.

In closing, Part III draws conclusions, compressed in scope and depth due to the short-form nature of this essay, about how the Strickler capital trial and its temporal dimensions further reveal the death penalty's crumbling edifice of legitimacy. The Strickler experience painfully signals that forty years of judicial, legislative, and executive fits and starts aimed at making the death

8. See McCleskey v. Kemp, 753 F.2d 877, 887 (11th Cir. 1985) (defendant presented statistical studies demonstrating that whether the victim was black or white may have an impact on applying the death penalty generally); cf. Ian Record, Two Indicted in Whitlock Abduction, BREEZE, Jan. 18, 1990, at 1 (describing Leann Whitlock as a sophomore psychology major and a member of a campus singing group).

9. See generally Michael N. Burt, The Importance of Storytelling at All Stages of a Capital Case, 77 UMKC L. REV. 877 (2009) (explaining how telling a dominant narrative that emphasizes the crime and its brutality can impact stages of a capital murder case).

10. See id. at 879 . 
penalty democratically "hygienic" have failed. Temporal arbitrariness courses through each and every death penalty case.

For those subjected to its reach, the story of the death penalty is one marked by the vagaries of time, place, and mood: disturbingly ephemeral bases for the ultimate sanction.

\section{NARRATIVE BACKGROUND: A LOOK AT THE FACTS AND THE LAW OF STRICKLER'S CAPITAL TRIAL}

On January 5, 1990, Leanne Whitlock, a James Madison University undergraduate student, disappeared after having borrowed her boyfriend's car. ${ }^{11}$ Eight days later, her body was found in a secluded area in Augusta County, Virginia. ${ }^{12}$ Strickler was arrested prior to the discovery of Whitlock's body and became connected to the disappearance by various witnesses who linked Strickler to the car and various belongings of Whitlock. ${ }^{13}$ An autopsy and the physical investigation of the area where Whitlock's body was found led to the prosecution's theory that Strickler and another man, Ronald L. Henderson, had killed Whitlock with a sixty-nine-pound boulder. ${ }^{14}$ Henderson was tried separately, convicted of first degree murder, and received three life sentences. ${ }^{15}$

To grapple temporally with this case requires an understanding of the prosecutor's narrative not only as to Strickler's guilt or innocence or the original charging decision, but also as to why Strickler was the "worst of the worst" and thus deserving of execution as a sentencing matter. This universal "winnowing" burden on prosecutors in death penalty cases is one reason for the emphasis on narrative in this summary.

A major component of this funneling process in the Strickler trial turned on a single witness named Anne Stoltzfus. She was the star witness who cemented the prosecutor's claim that Strick-

11. Strickler, 527 U.S. at 266-67.

12. Id. at 276; Strickler v. Commonwealth, 404 S.E.2d 227, 231 (Va. 1991).

13. Strickler, 404 S.E.2d. at 231 (indicating that Strickler was arrested on January 11); Record, supra note 8, at 1 (stating that Whitlock's body was discovered by police on January 13).

14. Strickler, 527 U.S. at 293 \& n.43; Strickler, 404 S.E.2d at 231.

15. See Mistake Shocks Slaying Victim's Parents, Free LAnCE-Star, Aug. 6, 1993, at C10. ler was depravє tice Kennedy's prived of a fair which sealed S timately, I can [and] the under. important is the

According to seen at a local s at the mall. ${ }^{20} \mathrm{~S}$ ] and eventual te derson's conduc Strickler and $\mathrm{H}$ while she and $h$ she later saw St into Whitlock's c that the events vehicle and repe

Not only did : edly witnessing ward until after crime, discovery search for Hend her story to the hended in Oreg Whitlock's car. ${ }^{26}$

16. See Strickler, 5

17. Id. at 307 (Sou

18. Id.

19. See Trial Tran with author) [hereinaft

20. Id. at 484-85.

21. Id. at 485-88; filed Oct. 15, 1997).

22. Strickler Trial '

23. Id. at 488-90.

24. Id. at 494-97.

25. Id. at 476 ; Str Stoltzfus testified to se officer until January 19

26. Man Charged I Strickler Given Death $P$ 
emporal arbitraralty case.

the death penalty nd mood: disturb-

CTS AND THE LAW

nes Madison Uniafter having borer body was found la. $^{12}$ Strickler was body and became hesses who linked Whitlock. ${ }^{13}$ An auwhere Whitlock's that Strickler and Whitlock with a d separately, conlife sentences. ${ }^{15}$

es an understandStrickler's guilt or ut also as to why deserving of exe"winnowing" burne reason for the s in the Strickler Stoltzfus. She was claim that Strick-

31 (Va. 1991).

was arrested on January $\mathrm{s}$ discovered by police on 231. CE-STAR, Aug. 6, 1993, at ler was depraved. ${ }^{16}$ Or, as stated by Justice Souter in his and Justice Kennedy's dissent in which they concluded Strickler was deprived of a fair trial, her testimony provided the "narrative force" which sealed Strickler's fate. ${ }^{17}$ Justice Souter further wrote, "U1timately, I cannot accept the Court's discount of Stoltzfus... [and] the undeniable narrative force of what she said.... What is important is that her evidence presented a gripping story." ${ }^{~}$

According to Stolzfus's testimony at trial, Whitlock was last seen at a local shopping center. ${ }^{19}$ She testified to seeing Whitlock at the mall. ${ }^{20}$ She also provided eyewitness information to police and eventual testimony at trial concerning Strickler's and Henderson's conduct at the mall. ${ }^{21}$ Stolzfus testified that she saw Strickler and Henderson behaving disruptively inside the mall while she and her fourteen-year-old daughter shopped, and that she later saw Strickler aggressively push and manhandle his way into Whitlock's car outside that same mall. ${ }^{22}$ She further testified that the events were alarming enough that she vacated her own vehicle and repeatedly asked Whitlock if she was okay. ${ }^{23}$

Not only did she not call the police immediately after purportedly witnessing a violent abduction, Stoltzfus did not come forward until after Strickler's arrest, heavy news coverage of the crime, discovery of the body, and a publicized interstate highway search for Henderson. ${ }^{24}$ Almost two weeks passed before she told her story to the authorities. ${ }^{25}$ Henderson was eventually apprehended in Oregon while Strickler was arrested in possession of Whitlock's car. ${ }^{26}$

16. See Strickler, 527 U.S. at 290 .

17. Id. at 307 (Souter, J., dissenting).

18. Id.

19. See Trial Transcript at 483-84, Commonwealth v. Strickler (Va. Cir. 1990) (on file with author) [hereinafter Strickler Trial Transcript].

20. Id. at $484-85$.

21. Id. at 485-88; Strickler v. Netherland, no. 3:95CV924, slip op. at 5-10 (E.D. Va. filed Oct. 15, 1997).

22. Strickler Trial Transcript, supra note 19 , at 476-80, 482, 485-87.

23. Id. at $488-90$.

24. Id. at 494-97.

25. Id. at 476; Strickler v. Greene, 527 U.S. 263, 273 (1999) (demonstrating that Stoltzfus testified to seeing the incident on January 5 but did not interview with a police officer until January 19).

26. Man Charged With Driving Student's Car, FREE LANCE-STAR, Jan. 12, 1991, at 24; Strickler Given Death Penalty, FREE LANCE-STAR, Sept. 20, 1990, at 39. 
As a legal matter, Stoltzfus was the most important witness at trial. Her testimony strongly supported the prosecution's theory that Strickler had committed the predicate offenses to capital murder of abduction and robbery. ${ }^{27}$ Throughout her testimony at trial, she referred to Strickler as "Mountain Man" and Henderson as "Shy Guy." 28 Defense counsel never objected to this. Predictably, the prosecution deployed this aggressive characterization of Strickler during the sentencing phase of the trial in its effort to persuade the jury that Strickler deserved the death sentence under Virginia law. ${ }^{29}$ During its closing statements, the prosecution also worked this theme as part of its narrative-a theme that would have been substantially weakened, if not entirely crippled, with defense access to Stoltzfus's contradictory statements. ${ }^{30}$

As outlined above, Stoltzfus was the jury's reportorial link to the awful events that the prosecution claimed led to the death of Whitlock. ${ }^{31}$ In effect, it was Stoltzfus who gave the jury its portrait of what occurred; there were no known witnesses to the brutal killing. ${ }^{32}$ Her description of Strickler's behavior at the mall laid not only a legal predicate for Strickler's culpability, but also the narrative foundation for the jury to classify Strickler as an alpha figure with a wantonly aggressive nature. ${ }^{33}$

Despite the clean, linear storyline at trial that Strickler was the ring-leader, there existed other Stoltzfus-generated evidence that never reached the proceedings and thus never became part

27. Though the Court in Strickler found that other evidence was sufficient to support the robbery charge, I would contend that the defendant is correct in that the robbery charge "flowed almost entirely from inferences from Stoltzfus' testimony." Strickler, 527 U.S. at $294-95$.

28. See, e.g., Strickler Trial Transcript, supra note 19, at 477-80.

29. Strickler, 527 U.S. at 305 ('[T] he Commonwealth's closing actually did include two brief references to Strickler's behavior in 'just grabbing a complete stranger and abducting her."').

30. See id. at 305-06 (Souter, J., dissenting) ("Stoltzfus's testimony helped establish the 'principle,' as the prosecutor put it, that Strickler was 'the aggressor,' the dominant figure, in the whole sequence of criminal events, including the murder, not just in the abduction. If the defense could have called Stoltzfus's credibility into question, the jurors' belief that Strickler was the chief aggressor might have been undermined to the point that at least one of them would have hesitated to recommend death.").

31. See supra notes $27-30$ and accompanying text.

32. See Strickler v. Netherland, No. 3:95CV924, slip op. at 13-14 (E.D. Va. filed Oct. 15, 1997); see also Elizabeth F. Loftus \& JAMES M. Doyle, Eyewitness Testimony: CIVIL AND CRIMINAL 5 (3d. ed. 1997) ("[R]esearch resoundingly proves that the story format is a powerful key to juror decision making.").

33. See supra notes $27-30$ and accompanying text. 
mportant witness at prosecution's theory offenses to capital ut her testimony at Ian" and Henderson ed to this. Predictacharacterization of trial in its effort to death sentence unnts, the prosecution tive - a theme that ot entirely crippled, $\tau$ statements. ${ }^{30}$

; reportorial link to l led to the death of ve the jury its porritnesses to the bruhavior at the mall sulpability, but also sify Strickler as an $e^{33}$

that Strickler was generated evidence never became part

e was sufficient to support prrect in that the robbery testimony." Strickler, 527

7-80.

ag actually did include two te stranger and abducting

estimony helped establish aggressor,' the dominant nurder, not just in the abinto question, the jurors' dermined to the point that

of the back-and-forth testing that is supposed to occur through evidence disclosure, cross-examination, and opening and closing arguments. Unknown to defense counsel was a bevy of conflicting statements that Stoltzfus made during her interactions with law enforcement. ${ }^{34}$ These communications were only uncovered during the course of federal habeas corpus investigation almost eight years after the trial. ${ }^{35}$

In one of these letters, Stoltzfus wrote to Detective Claytor, the investigating detective who interviewed her previously:

I want to clarify some of my confusion for you. First of all, I tend to remember things in pictures rather than in over-all logical constructs. When I didn't remember any Mall purchases, I didn't remember being there. But my 14-year-old daughter Katie remembers different things and her sharing with me what she remembers helped me jo[g] my memory. ${ }^{36}$

In that same letter, she also apologized for her "initial times [being] so far off," and explained that she "placed the time around 9:00 pm thinking [she] must have not gone in because the Mall was closing." Stoltzfus then explained that her new certainty about dates and times was based upon what her daughter and another person at the mall told her. ${ }^{37}$

Stoltzfus also admitted in this letter that she recalled visiting a store in the mall and only later, on the way back from that store, hearing a man in the mall yelling at a woman. She said that he "could have been the same guy who knocked on the [victim's] car window." She related "a very vague memory that [she was] not sure of," stating, "It seems as if the wild guy that I saw" earlier had run up to a bus, missed it, and then approached the blue car. $^{39}$ She wondered, "Were those 2 memories the same person?"40

This was not the only exculpatory letter she wrote to the investigating detective. On January 25, 1990, she wrote that she "spent several hours with John Dean [the victim's boyfriend] looking at current photos from which [she] made the identification [of

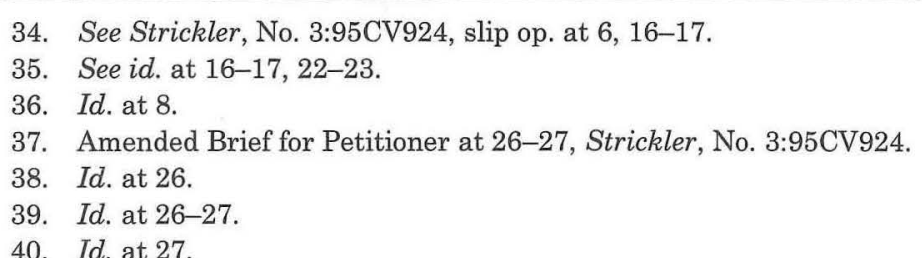


the victim]." She also thanked the detective for his "patience with [her] sometimes muddled memories." She stated that she "didn't believe [a crime was] what [she] saw until [she] saw Leanne's pictures." ${ }^{\text {"Sh }}$ She admitted that, without the detective's help, she "never would have made any of the associations" that she made. ${ }^{44}$

According to Judge Merhige, the district court judge presiding over Strickler's federal habeas corpus review in the Eastern District of Virginia, these admissions of the unreliability of her memory were so significant, "[I]t provides a basis for which Stoltzfus's testimony might have been excluded altogether." ${ }^{\$ 45}$ Even if not excludable, these admissions were directly and powerfully contradicted, and therefore, they could have impeached her testimony at trial.

Although it took several hours with the victim's boyfriend and pictures of the victim before Stoltzfus could identify Whitlock to the police, at trial she described Whitlock at the mall as being "a rich college kid," "singing" and "happy." At trial, she also described the clothing Whitlock was wearing. ${ }^{47}$ The inconsistencies with regard to the degree of detail she described to the investigators "were extremely material for cross-examination." ${ }^{48}$

There were other significant issues with Stoltzfus's testimony. At trial, she claimed she was "one hundred percent sure" of her identification of Strickler from photographs that the investigators gave to her. ${ }^{49}$ However, according to the detective's report, "she could not positively identify Strickler but stated only that he 'resembled' one of the men she had seen. Stoltzfus stated that his hair color was not right."

The foregoing statements were not part of the documents that Strickler's defense counsel had access to via the Augusta County

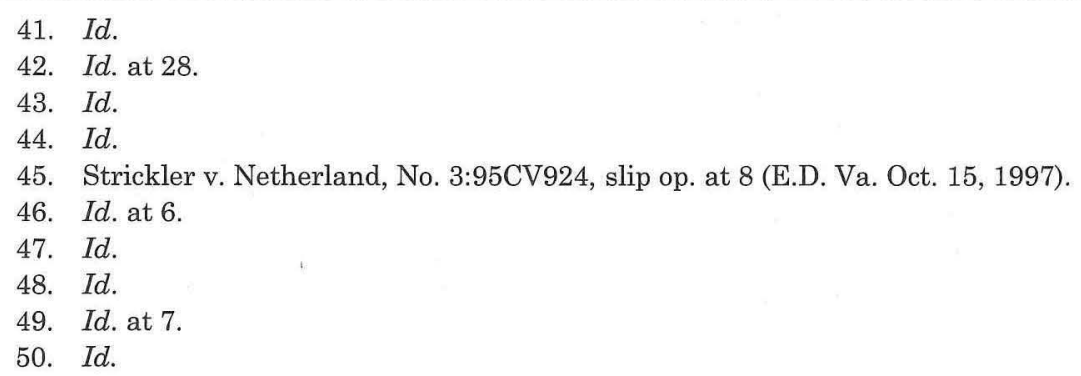


for his "patience e stated that she until [she] saw ut the detective's associations" that

t judge presiding the Eastern Disreliability of her basis for which led altogether." rectly and powerre impeached her

n's boyfriend and ntify Whitlock to mall as being "a rial, she also dee inconsistencies to the investigaion. ${ }^{348}$

zfus's testimony. cent sure" of her the investigators ive's report, "she only that he "res stated that his

Commonwealth Attorney's "open file" policy. They were part of the detective's file and never merged into the prosecutor's file. ${ }^{51}$ Open file policies are meant to operationalize transparency, enforce Brady v. Maryland's edict that prosecutors disclose exculpatory evidence to defendants' counsel prior to trial, and enhance efficiency by allowing defense counsel to review any and all documents within the prosecutor's domain. ${ }^{52}$

To work properly, the open file system depends on both good faith and good management. Open file policies depend on cooperation between law enforcement and the prosecution in order to ensure that the files that the defense counsel review reflect the totality of relevant information. In Strickler's case there was an obvious breakdown in cooperation or shared knowledge on law enforcement's part. Clearly, this information would have been valuable to Strickler's defense and its capacity to offset the prosecutor's ringleader theory of culpability.

Not surprisingly, the nondisclosure of the Stoltzfus materials colored the basic character of the prosecution's trial narrative. ${ }^{53}$ The vacuum left little space for the defense to counter the aggressive portrait of Strickler that Stoltzfus painted. To be sure, it made it harder to question the underlying felonies that exposed Strickler to the death penalty. Additionally, it foreclosed potential avenues of further pre-trial investigation. After all, the particular details in the letters would (or should) have caused defense counsel to pursue those leads.

That said, this essay's raison d'etre is not to argue a legalistic Brady reformulation of Strickler's case. Brady claims are always challenging to win due to post-conviction relief's existential battle

51. See id. at 17 .

52. 373 U.S. 83,87 (1963) (holding that "the suppression by the prosecution of evidence favorable to an accused upon request violates due process where the evidence is material either to guilt or to punishment, irrespective of the good faith or bad faith of the prosecution"). See generally Bennett L. Gershman, Litigating Brady v. Maryland: Games Prosecutors Play, 57 CASE W. RES. L. REV. 531 (2007) (discussing how prosecutors often don't fulfill their Brady obligations of turning over law enforcement files).

53. Strickler, No. 3:95CV924, slip op. at 11-14; see also William J. Bowers et al., Foreclosed Impartiality in Capital Sentencing: Jurors' Predispositions, Guilt-Trial Experience, and Premature Decision Making, 83 CORNELL L. REV. 1476, 1493 (1998) (demonstrating that evidence and arguments presented during guilt phase of a capital trial will impact sentencing decisions of juries). 
with the legal system's preference for finality. ${ }^{54}$ More primitively, post-conviction litigation must do battle with "confirmation bias," the strong human desire to preserve initial beliefs, opinions, and conclusions. ${ }^{55}$ Although I believe the Court missed the mark in its Brady ruling, my purpose here is to re-imagine the trial in light of current doctrinal, capital defense, and normative realities driving capital litigation in today's Virginia.

In short, I strive to lift the veil on the death penalty's temporal arbitrariness by taking stock of important changed circumstances as they relate to Strickler's capital trial and its narrative, not his federal habeas corpus litigation. It may be tempting to push aside my thought experiment as mere counterfactual prodding, but any capital punishment regime should be prepared to answer all manner of inquiry. Death penalty regimes warrant a wide range of review: cost review, fairness review, demographic review, accuracy review, deterrent review, and even the kind of "soft" temporal review underway here. Although we live in an age of empiricism, the democratic currency of our legal system is fundamental fairness and due process, two distinctly qualitative notions which strongly animate the core of America's civic identity. ${ }^{56}$ So with that in mind, what can we say about the fairness of Strickler's trial when viewed from a different point in time-a time marked by different doctrine, mores, and resources?

\section{THE TEMPORAL ZONE OF STRICKLER'S CAPITAL MURDER TRIAL: DOCTRINE, NORMS, AND RESOURCES}

\section{A. Strickler's Limited Intellectual Capacity and Sentencing: Atkins v. Virginia and Increased Emphasis on the Role of Mitigation}

Strickler's status as "borderline" mentally retarded and his background of severe deprivations were not narratively brought

54. See Gershman, supra note 52, at 562.

55. See Richard A. Posner, How Judges THINK 111 (2008). See generally Goutam U. Jois, Stare Decisis Is Cognitive Error, 75 BRooK. L. REV. 63, 64-65 (2009) (arguing that psychological evidence of cognitive bias gives reason to reject stare decisis).

56. See Sawyer v. Hauck, 245 F. Supp. 55, 57 (W.D. Texas 1965); Margaret Jane Radin, Cruel Punishment and Respect for Persons: Super Due Process for Death, 53 S. CAL. L. REV. 1143, 1151 (1980). 
More primitively, nfirmation bias," ifs, opinions, and $\mathrm{d}$ the mark in its the trial in light .ve realities driv-

nalty's temporal d circumstances larrative, not his ng to push aside rodding, but any $x$ to answer all int a wide range hic review, accuid of "soft" teman age of empir1 is fundamental re notions which entity. ${ }^{56}$ So with ss of Strickler's -a time marked

MURDER TRIAL:

entencing:

the Role of

tarded and his atively brought

generally Goutam U. (2009) (arguing that isis).

; Margaret Jane RaDeath, 53 S. CAL. L. into focus during Strickler's sentencing phase. ${ }^{57}$ An omission of this scope is a near de facto reflection of an absence of defense mitigation strategy. ${ }^{58} \mathrm{I}$ discuss intellectual disability separately from the broader psychosocial history, but it is important to remember they are inextricably linked as a matter of capital defense litigation. These evidence categories are directly related to divining who is the "worst of the worst"-a stated constitutional necessity for any death penalty regime. ${ }^{59}$ Mitigation is the very heart of defense counsel's role at sentencing. ${ }^{60}$ Both Strickler's intellectual deficits and his upbringing were essential ingredients for launching a defense against the prosecution's mission to secure the death penalty. The sentencing transcript reveals little more than defense counsel's anemic communication of undeveloped evidentiary scraps hinting at childhood hardships and intellectual challenges. ${ }^{61}$ In other words, Strickler's chief mitigating factors were left untapped.

Highlighting the overarching structural role of mitigation, the ABA describes counsel's duty to fashion a mitigation strategy as global in nature. It states, "The duty to investigate, develop and pursue avenues relevant to mitigation of the offense or penalty, and to effectively communicate the fruits of those efforts to the decision-makers, rests upon defense counsel." ${ }^{\prime 2}$ The duty to marshal and present mitigation evidence in a capital case attaches to all stages of the proceedings. ${ }^{63}$ Toward this end, defense counsel's responsibility to create a mitigation strategy in narrative form cannot be overstated. ${ }^{64}$

Unlike the intentional, targeted, and integrated mitigation approach that the ABA envisions, Strickler's defense counsel essentially rendered his intellectual profile meaningless by neglecting

57. Sentencing Transcript at 878-79, Commonwealth v. Strickler (Va. Cir. 1990) (on file with author).

58. See Lockett v. Ohio, 438 U.S. 586, 605 (1978); Woodson v. North Carolina, 428 U.S. 280, 304 (1976) (both demonstrating the factual need to present individualized consideration in order for the death penalty to be constitutional).

59. See Woodson, 428 U.S. at 304.

60. Supplementary Guidelines for the Mitigation Function of Defense Teams in Death Penalty Cases, 36 HofSTRA L. REV. 677, 677 (2008) [hereinafter Supplementary Mitigation Guidelines].

61. Sentencing Transcript, supra note 57 , at $34,36,38,40,42,878-98$.

62. Supplementary Mitigation Guidelines, supra note 60 , at 678.

63. Id.

64. See Burt, supra note 9, at 879 (internal citations omitted). 
to develop and contextualize its significance. Strickler's IQ was measured to be 75 , a number that soundly placed him within the zone of the intellectually limited. ${ }^{6 \overline{5}}$ Strickler's counsel called a neuropsychologist who examined Strickler for intellectual functioning to testify at the sentencing phase. ${ }^{66}$ The total direct examination of the neuropsychologist was three-and-one-half pages long. ${ }^{67}$ One-and-one-half-pages detailed the neuropsychologist's credentials. ${ }^{68}$ Defense counsel's only substantive questions directed to the neuropsychologist were the following:

Question: What does that [IQ of seventy-five] mean in terms of his range?

Answer: A full scale IQ of seventy-five places his intellectual functioning in a borderline range. The borderline range is in between mentally retarded and the low average range.

Question: How many people in his age group would be above him in IQ?

Answer: The average twenty-four-year-old male in the United States would achieve an IQ of a hundred so that places him at [the] fifty percentile. Meaning that ninety-five percent of individuals his age and educational background would achieve IQs higher than what he achieved.

Question: Is that, would that in anyway affect his decision making processes?

Answer: Intellectual tests are tests of verbal questions and visual and motor tasks that give an idea of how well someone thinks with regard to cognition, making appropriate choices, being able to work efficiently with their hands and it can be an indicator of how well someone will do, say, on a job or in school. ${ }^{69}$

Unfortunately for both Strickler and for society's interest in zealous representation in capital trials, this line of questioning ended with the above. ${ }^{70}$ Defense counsel then immediately turned to five final questions requesting the names of the cognitive tests used and requesting minor details about how blocks are applied

65. Sentencing Transcript, supra note 57, at 878-79 (testimony of Dr. Thomas Ryan).

66. Id. at $878-82$.

67. Id. at $878-81$.

68. Id. at $878-79$.

69. Id. at 879-80.

70. Id. at 880 .

in such testing. testing methods counsel to educ limitations hav ness, reasoning,

Beyond the is ler's other mitis (i.e., the detail family, social, a: from the neurop testify at the se were asked on a was called appa turned a borrow borhood, was ce stayed at her ho ther questions tions. $^{80}$ The tran morialization of witnesses. ${ }^{81}$

In fact, the $\mathrm{ps}$ asked to review at the top of its nor defense cou any effort to obt been minimally quate presentati

How would a actors-law enf

71. Id. at $880-81$.

72. Id.

73. Id.at 878-81.

74. Id. at $882-98$.

75. Id. at $883-85$,

76. Id. at 883-98 (

77. Id. at $892-93$.

78. Id. at 883 .

79. Id.

80. Id.

81. Id. at 878-98.

82. JANET WARREN 
Strickler's IQ was ced him within the 's counsel called a $r$ intellectual funca total direct examand-one-half pages neuropsychologist's ttive questions diing:

$\mathrm{n}$ in terms of his

intellectual funcge is in between

be above him in

he United States uim at [the] fifty dividuals his age ter than what he

decision making

ions and visual one thinks with ng able to work tor of how well

ciety's interest in ne of questioning mediately turned he cognitive tests locks are applied in such testing. ${ }^{71}$ The questioning faded into a blasé treatment of testing methods. ${ }^{72}$ Glaringly absent were any attempts by defense counsel to educate the jurors concerning the effects intellectual limitations have on an individual's memory, judgment, awareness, reasoning, and social interactions. ${ }^{73}$

Beyond the issue of Strickler's limited cognitive ability, Strickler's other mitigation evidence, namely his psychosocial history (i.e., the detailed, exhaustive analysis of educational, medical, family, social, and other personal data) was directionless. ${ }^{74}$ Apart from the neuropsychologist, the additional five witnesses called to testify at the sentencing phase were family and friends. ${ }^{75}$ They were asked on average ten questions. ${ }^{76}$ One witness, a neighbor, was called apparently to recount how as a young boy Strickler returned a borrowed bike. ${ }^{77}$ Another witness, also from the neighborhood, was called and asked simply whether Strickler ever stayed at her house. ${ }^{78}$ She answered in the affirmative and no further questions were asked. ${ }^{79}$ Her testimony totaled seven questions. $^{80}$ The transcript is a mere twenty-one pages long in its memorialization of defense counsel's direct examination of all six witnesses. ${ }^{81}$

In fact, the psychosocial report produced by the social worker asked to review Strickler's past was labeled "Not a Final Report" at the top of its cover sheet. ${ }^{82}$ Nonetheless, neither the transcript nor defense counsel's files indicated that defense counsel made any effort to obtain a complete report. Such a report would have been minimally necessary for any hope of a substantively adequate presentation of Strickler's background.

How would a contemporary capital trial and its institutional actors-law enforcement, prosecutor, defense counsel, and ju-

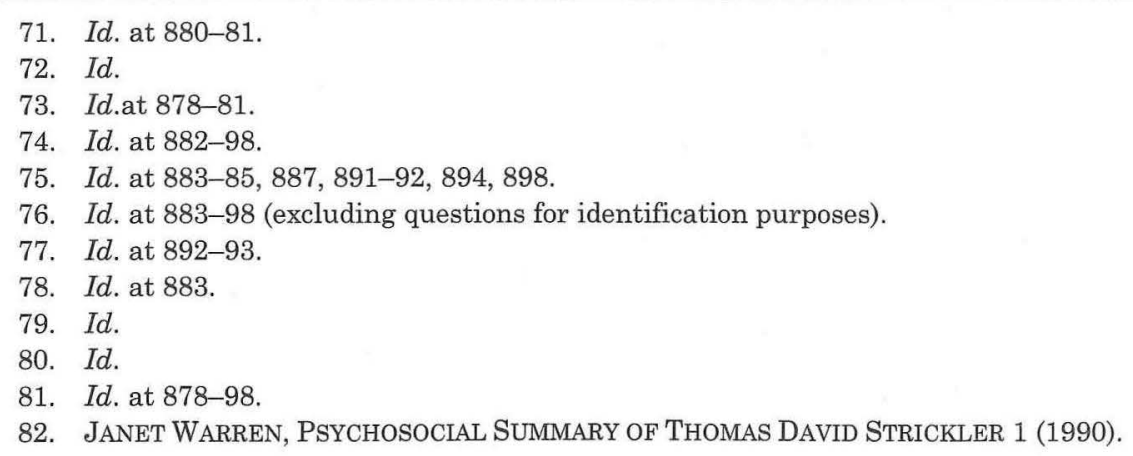


rors-confront Strickler's intellectual make-up and his psychosocial history if Strickler were charged, tried, and sentenced in 2015 ?

First, Strickler's intellectual profile is a major window into how time has altered the capital litigation landscape. From a doctrinal perspective, the ground has shifted enormously since Strickler's trial in the arena of protections for the intellectually disabled. In 2002, the Court ruled in Atkins v. Virginia that executing intellectually disabled persons violates the Eighth Amendment's ban on cruel and unusual punishments. ${ }^{83}$ The Court devised a threeprong analysis for determining intellectual disability: (1) the individual must show significant subaverage intellectual functioning, (2) the individual must have significant limitations in adaptive functioning for everyday living, and (3) the individual must have experienced these deficits prior to the age of eighteen. ${ }^{84}$

Consistent with America's decentralized criminal justice model, the Court left to the states the role of implementing the particulars of this paradigm, yet recently held in Florida $v$. Hall that the states cannot set a fixed numerical demarcation within the margin of error on any given intelligence test. ${ }^{85}$ Relevant to the evidence surrounding Strickler's intellectual status, the Court in Hall invalidated Florida's scheme, which enforced a strict limit against any exclusions for individuals with IQs over $70 .^{86}$ The language of Virginia's death penalty regime has been interpreted by courts to have the same numerical break point of the sort invalidated in Hall. ${ }^{87}$

When the Court announces new categorically driven constitutional constraints in cases like Atkins, in which residual proce-

83. 536 U.S. 304, 321 (2002) (overruling Penry v. Lynaugh, 492 U.S. 302 (1989)).

84. Id. at 318 .

85. See Hall v. Florida, 572 U.S. 134 S. Ct. 1986, 2000-01 (2014) (holding that although the State can set the parameters for defining disability, it must not foreclose further exploration of a potential intellectual disability if IQ score is within margin of error).

86. Id. at — 134 S. Ct. at $1994,2000$.

87. Compare VA. CoDE ANN. § 19.2-264.3:1.1 (2008) (requiring at least two standard deviations below the mean on a standardized intellectual functioning test) and Hedrick v. True, 443 F.3d 342, 366-67 (2006) (finding that an IQ of 70 or less corresponds with the two standard deviations, below the mean requirement) (citing Johnson v. Commonwealth, 591 S.E.2d 47, 59 (2005) (vacated on other grounds); Walker v. True, 399 F.3d 315, 320 (2005)), with Hall, 572 U.S. — 134 S. Ct. 1986 (invalidating a Florida statute that requires the same two standard deviations as the Virginia statute). dural and de landscapes ch to end, this d pact the pros today. Atkins' al litigation $\mathrm{cc}$ normative res pact the deci death penalty tors are less w ing to impose

While Stric abilities, this : setting and co nection with would fall witl the Hall case. kins dissent a death row inm $15 \%$ of capital across the nati

The attenua pability was or portantly, thes before the Cou bled. A Sixth lawyer deemed because he fail the defendant's ity. ${ }^{92}$ The Cour

88. See generally its Application in $\mathrm{Ca}$ ly that post-Atkins li

89. Sentencing T and Dr. Thomas Ryar

90. Blume et al.,

91. Id. at 632

92. Dickerson v. 
and his psychosoand sentenced in

: window into how - From a doctrinal y since Strickler's iually disabled. In it executing intelAmendment's ban $t$ devised a threeability: (1) the inllectual functionnitations in adapa individual must of eighteen. ${ }^{84}$

nal justice model, nting the particu'a $v$. Hall that the 1 within the marlevant to the evius, the Court in ced a strict limit Qs over $70 .^{86}$ The been interpreted int of the sort in-

driven constituh residual proce-

U.S. 302 (1989)).

2000-01 (2014) (holding ity, it must not foreclose is within margin of er-

gat least two standard ing test) and Hedrick v. ss corresponds with the ison v. Commonwealth, rue, 399 F.3d 315, 320 Florida statute that re- dural and definitional authority remains with the states, legal landscapes change in front-line, practical ways. From beginning to end, this different reality would strategically and fiscally impact the prosecution's approach to Strickler's case if it unfolded today. Atkins's operational costs posed by the specter of additional litigation concerning the issue of intellectual disability and the normative resistance to violating its moral meaning clearly impact the decisionmaking of various institutional actors in the death penalty arena all across the nation. ${ }^{88}$ After Atkins, prosecutors are less willing to seek the death penalty, juries are less willing to impose it, and judges are less willing to uphold it.

While Strickler was deemed only "borderline" in his cognitive abilities, this status would still carry more weight in today's legal setting and could be used in plea negotiations or litigated in connection with sentencing. ${ }^{89}$ To be sure, Strickler's measurement would fall within the margin-of-error zone deemed problematic in the Hall case. Overall, despite Justice Scalia's concern in the Atkins dissent about an avalanche of frivolous claims, only $7 \%$ of death row inmates had litigated this issue as of $2009 .{ }^{90}$ In fact, $15 \%$ of capital defendants who successfully litigated Atkins claims across the nation have had IQs measured above $70 .^{91}$

The attenuated linkage between intellectual disability and culpability was one of the main rationales for the Atkins ruling. Importantly, these arguments were being made at sentencing long before the Court outlawed the execution of the intellectually disabled. A Sixth Circuit habeas case from 2006 involved a defense lawyer deemed ineffective for his sentencing performance in part because he failed to investigate and present mitigation related to the defendant's IQ of 77 as a basis for arguing reduced culpability. ${ }^{92}$ The Court of Appeals expressly noted the arguments under-

88. See generally John H. Blume et al., An Empirical Look at Atkins v. Virginia and its Application in Capital Cases, 76 TENN. L. REV. 625 (2009) (demonstrating quantitatively that post-Atkins litigation has not seen a flood of frivolous claims).

89. Sentencing Transcript, supra note 57, at 42, 879 (testimony of Dr. Janet Warren and Dr. Thomas Ryan).

90. Blume et al., supra note 88 , at 628 .

91. Id. at 632 .

92. Dickerson v. Bagley, 453 F.3d 690, 691-92 (6th Cir. 2006). 
girding the Atkins ruling as the foundation for what should have been defense counsel's mitigation narrative. ${ }^{93}$

From the data we have thus far concerning successful Atkins claims and in light of Hall, we now know that in the hands of capable capital defense counsel, Strickler's intellectual profile would be eminently contestable in terms of a legal bar prohibiting his execution and be powerfully resonant in relation to plea negotiations and sentencing mitigation strategy. Now it would be vetted by the full array of institutional actors charged with the administration of the death penalty in Virginia. Simply put, after Atkins and Hall, IQ and adaptive functioning would be a centerpiece of Strickler's defense team's approach in Virginia's contemporary capital defense litigation.

Another altered dimension in today's capital defense litigation is a greater, more muscular approach to the role of mitigation, especially as it pertains to the all-important sentencing phase. One year before Strickler's trial in 1989, the ABA set forth comprehensive guidelines for the appointment and performance of counsel in capital cases, describing the expansive range of duties required to deliver effective representation in such cases. ${ }^{94}$ Those tasks included investigation into a defendant's medical history, special educational needs, employment history, family background, cultural environment, and other detailed biographical information. $^{95}$ In 2003, the ABA returned to the subject of capital defense when it produced more guidance stating that effective capital defense necessitated the coordinated and collaborative work of a team of experts-lawyers, fact investigators, mitigation specialists, and other professionals. ${ }^{96}$ These standards have slowly, but imperfectly, taken root in the professional culture surrounding death penalty litigation. They were not widely at play in 1990 when Strickler was tried and sentenced.

Professors Carol and Jordan Steiker have addressed the ascendancy of mitigation in death penalty litigation over the last twenty or twenty-five years in their analysis of how death penalty

93. Id. at 698.

94. Am. Bar Ass'N, Guidelines for the Appointment and Performance of Counsel in Death Penalty Cases (1989).

95. Id. at $11.4 .1 \S 2(\mathrm{C})$.

96. See AM. BAR Ass'N, Guidelines for the Appointment and Performance of Defense Counsel in Death Penalty Cases, 31 HofSTRA L. REV. 913, 955 (2003). 
reforms are aligning at a functional level with abolitionist goals. ${ }^{97}$ They write:

The transformation of capital-trial defense, reflected in the ABA standards (though not fully in capital practice) has been destabilizing to the continued use of the death penalty in at least two ways. First, like the additional layers of procedural safeguards wrought by increased legal regulation, the emergence of robust individualization and other trial-preparation standards has dramatically raised the cost of capital punishment. Capital-trial costs are stunningly greater than their noncapital counterparts. Second, robust individualization fits uneasily with many of the traditional and religious defenses of the death penalty, because it presumes that "an eye for an eye" is an inappropriate command; the death penalty decision must be as much a judgment about the offender as the offense. ${ }^{98}$

In addition to evidence of Strickler's intellectual impairment, there was ample traditional mitigation evidence which would be more fully mined in today's mitigation-centered capital defense ethos. Strickler's life was replete with mitigation evidence. Multifaceted evidence existed to show that Strickler left school at the age of sixteen in the eighth grade, suffered severe violence at the hands of his alcoholic stepfather, and had signs of organic brain dysfunction..$^{99}$ Defense counsel also omitted Strickler's drug addiction. ${ }^{100}$ His older sister and mother reported a chronic atmosphere of violence in Strickler's home. ${ }^{101}$ He was thrown off a truck by a family member at age three and suffered a fractured leg, and his older siblings routinely struck him. ${ }^{102}$ Post-conviction investigation also revealed multiple sources establishing that Strickler was often homeless during his childhood as a result of being ex-

97. See generally Carol S. Steiker \& Jordan M. Steiker, Entrenchment and/or Destabilization? Reflections on (Another) Two Decades of Constitutional Regulation of Capital Punishment, 30 L. \& INEQ. 211 (2012).

98. Id. at 233 .

99. See Sentencing Transcript, supra note 57, at 34-43, 878-98; Amended Petition for Writ of Habeas Corpus at 47-48, Strickler v. Netherland, No. 3:95CV924 (E.D. Va. filed May 20, 1996).

100. See Sentencing Transcript, supra note 57, at 889-91; Amended Petition, supra note 99 , at 45 .

101. See Sentencing Transcript, supra note 57, at 887-91, 896-98; Amended Petition, supra note 99 , at 48 .

102. See Amended Petition, supra note 99, at 48. 
pelled by his stepfather. ${ }^{103}$ Strickler's bouts with homelessness predated him entering puberty. ${ }^{104}$

Not only has the legal profession elevated the significance of mitigation strategy since Strickler's trial, but the Supreme Court has also been more willing to require it as part of the Sixth Amendment right to effective assistance of counsel. ${ }^{105}$ One example is Rompilla $v$. Beard. ${ }^{106}$ In Rompilla, the Court found that defense representation fell below the level of reasonable performance when counsel did not investigate their capitally charged defendant's previous conviction. ${ }^{107}$ The Court concluded that investigating the prosecutor's file relating to the defendant's prior conviction would have unearthed important information about the defendant's limited intellectual functioning. ${ }^{108}$

In light of Rompilla and other cases, the Court appears ready to be a partner in the profession's sustained focus on the centrality of mitigation strategy. ${ }^{109}$ Even as ineffective assistance of counsel claims remain difficult to win, the Court is identifying mitigation evidence and strategy as a cornerstone in the delivery of a constitutionally adequate capital trial. Interestingly, Justice Souter highlighted the ABA's standards for capital defense counsel in noting that lawyers should now be very cognizant of mitigation evidence as an essential part of constitutionally reasonable representation. ${ }^{110}$

Despite the essential role of mitigation in capital sentencing, a mitigation strategy never made its way into the jury's narrative understanding of Strickler's life. A detailed, comprehensive miti-

103. See Sentencing Transcript, supra note 57, at 897; Amended Petition, supra note 99 , at 48 .

104. See Sentencing Transcript, supra note 57, at 897 (discussing how Strickler had to "strike out on his own" at a young age after being kicked out of the house by his stepfather).

105. See Rompilla v. Beard, 545 U.S. 374, 377 (2005); see also Strickland v. Washington, 466 U.S. 668, 687 (1984) (setting forth the two-prong test for ineffective assistance of counsel).

106. 545 U.S. 374.

107. Id. at 382-83, 389 .

108. Id. at $382-83$.

109. See generally Sears v. Upton, 561 U.S. 945, 946 (2010) (finding that the state court failed to apply the correct prejudice inquiry when "counsel did present some mitigation evidence during Sears' penalty phase-but not the significant mitigation evidence a constitutionally adequate investigation would have uncovered").

110. Rompilla, 545 U.S. at 387-88 \& n.6-7. gation narrative had a human $\mathrm{p}$ Man." $" 111$ A well-c counter the dera fus's testimony his childhood der igation which sh framework for $\mathrm{m}$

In sum, Strick vision to humani Post-Atkins and of mitigation evi phase of his capi present moment tive.

\section{B. Declining Pub Pursuit of, the}

Strickler was s was second only Americans were and in Virginia Furman v. Geor were executed in ally, Democrats s and Republicans

Why 1999 was in modern Ameri

111. See Strickler v. scription of Strickler as "

112. See supra notes

113. Executions in th altyinfo.org/executions-u

114. Executions by $S$ altyinfo.org/node/5741\#V Year] (Virginia executior CTR., http://www.deathp after Executions by Year] 115. Executions by St 116. 7 in 10 Favor De 
he significance of he Supreme Court part of the Sixth asel. ${ }^{105}$ One examurt found that deeasonable perforcapitally charged oncluded that indefendant's prior nformation about 108

urt appears ready us on the centraliassistance of coundentifying mitigathe delivery of a estingly, Justice ital defense coungnizant of mitigaonally reasonable

ital sentencing, a e jury's narrative mprehensive miti-

ded Petition, supra note ing how Strickler had to the house by his stepfaStrickland v. Washingineffective assistance of

ding that the state court oresent some mitigation tigation evidence a con- gation narrative, at a minimum, would have meant that the jury had a human picture of a man they knew only as "Mountain Man."111 A well-crafted mitigation strategy had the potential to counter the deranged ringleader depiction of Strickler that Stoltzfus's testimony presented. ${ }^{112}$ Strickler's intellectual deficits and his childhood deprivations were strong independent bases for mitigation which should have been developed in a complementary framework for maximum effect.

In sum, Strickler was sentenced without any targeted, strategic vision to humanize him in the minds and the hearts of the jurors. Post-Atkins and with the heightened emphasis on the importance of mitigation evidence in recent decades, Strickler's sentencing phase of his capital trial would be markedly more robust in the present moment in strategy, investigation, framing, and narrative.

\section{B. Declining Public Support for, and Declining Prosecutorial Pursuit of, the Death Penalty}

Strickler was sentenced and executed at a time when Virginia was second only to Texas in total executions. ${ }^{113}$ Indeed, more Americans were put to death in 1999, both at the national level and in Virginia at the state level, than any other year postFurman v. Georgia. ${ }^{114}$ Strickler and thirteen other Virginians were executed in the last year of the twentieth century. ${ }^{115}$ Nationally, Democrats supported the death penalty 2-1 during this time and Republicans supported it 7-1. ${ }^{116}$

Why 1999 was the numeric high point of state sanctioned death in modern America is a complicated question with a host of as-

111. See Strickler v. Greene, 527 U.S. 263, 270-73 (1999) (describing Stoltzfus's description of Strickler as "Mountain Man" to the jury).

112. See supra notes 19-44 and accompanying text.

113. Executions in the U.S. in 1999, DEATH PENALTY INFO. CTR., http://www.deathpen altyinfo.org/executions-us-1999 (last visited Feb. 27, 2015).

114. Executions by State and Year, DeATH PENALty InFo. CTR., http://www.deathpen altyinfo.org/node/5741\#VA (last visited Feb. 27, 2015) [hereinafter Executions by State and Year] (Virginia execution statistics over time); Executions by Year, DEATH PENALTY INFO. CTR., http://www.deathpenaltyinfo.org/executions-year (last visited Feb. 27, 2015) [hereinafter Executions by Year] (national execution statistics over time).

115. Executions by State and Year, supra note 114.

116. 7 in 10 Favor Death Penalty for Murder, GALLUP REP., Jan.-Feb. 1986, at 10. 
serted explanations. My colleague, Professor Corinna Barrett Lain, writes that this era was one characterized by a "jurisprudential trend that was exceedingly hostile to death penalty challenges - and that trend was, in turn, part of a larger sociopolitical trend moving the same way." 117 In the first nearly twenty years of the death penalty's modern era, prior to any definitive evidence to the contrary, many Americans could assume that the death penalty's asserted retributive purpose was unsullied. ${ }^{118}$ In short, the death penalty had many friends at all levels of the democratic pyramid-voters, jurors, prosecutors, judges-and it had yet to be questioned scientifically with the DNA revolution.

In terms of the national electoral climate, the "tough on crime" political ethos that followed the 1960s was deeply entrenched by the time many of the trials that gave rise to the 1999 cohort of executions occurred. ${ }^{119}$ On average, those executed in 1999 spent nearly twelve years on death row between their sentencing and execution. ${ }^{120}$ Thus, many of these defendants had been tried in the 1980s. That decade saw the beginning of the war on drugs era and the unveiling of the Willie Horton ad, which helped cripple Michael Dukakis's presidential campaign by marginalizing him as soft on crime. ${ }^{121}$ The gruesome cable-televised coverage of Ted Bundy's execution for the serial murders of young Floridian women has even been suggested as a factor in the country's death penalty support. ${ }^{122}$

And what does today look like in terms of public support for the death penalty across the nation and in Virginia? Are capital trials affected by the ebb and flow of public support?

117. Corinna Barrett Lain, Deciding Death, 57 DukE L.J. 1, 43 (2007) (emphasis in original).

118. See Scott Shane, A Death Penalty Fight Comes Home, N.Y. TIMES, Feb. 6, 2013, at A14 (discussing Kirk Bloodsworth who, in 1993, was the first death row inmate to be exonerated by DNA evidence); see also Maryland, DEATH PENALTY INFO. CTR., http://www. deathpenaltyinfo.org/maryland-1 (last visited Feb. 27, 2015).

119. See infra notes 120-22 and accompanying text.

120. Time on Death Row, DEATH PENALTY INFO. CTR., http://www.deathpenaltyinfo.org/ time-death-row (last visited Feb. 27, 2015).

121. See Op-Ed., George Bush and Willie Horton, N.Y. TIMES (Nov. 4, 1988), available at http://www.nytimes.com/1988/11/04/opinion/george-bush-and-willie-horton.html.

122. See James Alan Fox et al., Death Penalty Opinion in the Post-Furman Years, 18 N.Y.U. ReV. L. \& SOC. CHANGE 499, 510 \& n.42 (1990) (discussing the Ted Bundy trial and its potential effect on public support for the death penalty). 

t the death pend. ${ }^{118}$ In short, the $f$ the democratic $d$ it had yet to be

"tough on crime" ly entrenched by e 1999 cohort of ed in 1999 spent sentencing and been tried in the ar on drugs era $\mathrm{h}$ helped cripple arginalizing him coverage of Ted g Floridian womcountry's death

c support for the Are capital trials ie-horton.html.

All these years after Strickler's trial, the death penalty is in decline in Virginia and across the nation. ${ }^{123}$ Maybe the fever has broken. ${ }^{124}$ In the Commonwealth, there are fewer capital murder indictments, fewer capital murder trials, fewer death sentences, and fewer executions now than since the death penalty's reinstatement. ${ }^{125}$

For many reasons, deconstructing why and how the death penalty has lost support and why the nation is producing fewer executions is beyond the scope of this essay. The death penalty is a varied phenomenon across the thirty-two states that maintain it. ${ }^{126}$ Thus, it is a creature of idiosyncratic political cultures with specific substantive and procedural laws governing death penalty schema. In other words, there is no unitary "death penalty" in the United States.

Notwithstanding the complex patchwork that makes up capital punishment in America, there are macro trends broadly accepted as being contributors to the declining support of the death penalty. As such, there is a working consensus among scholars and other observers concerning the factors giving rise to this important development.

A widely noted contributing factor to the decline of the death penalty is the DNA revolution and the exonerations it thrust un-

123. Executions by State and Year, supra note 114; Executions by Year, supra note 114.

124. See generally John G. Douglass, Death as a Bargaining Chip: Plea Bargaining and the Future of Virginia's Death Penalty, 49 U. RICH. L. REV. _ (2015) (discussing the current decline in death penalty use and the current practices surrounding the death penalty).

125. See Douglass, supra note 124, at _. Compare ACLU of VA., UNEQUAL, UNFAIR and Irreversible: The Death Penalty in Virginia 3 (2000) [hereinafter Unequal, UNFAIR AND IRREVERSIBLE], available at www.acluva.org/publications/deathpenaltystudy. pdf (noting that in the 18 years between 1982, when Virginia executed its first inmate under post-Furman death penalty law, and 2000, there were 81 executions), with AM. BAR Ass'n, Evaluating Fairness and ACcuracy in State Death Penalty Systems: The Virginia DeAth Penalty Assessment Report 1 (2013) (noting that between 1975 and 2013, Virginia executed 110 inmates, meaning that in the 13 years between 2000 and 2013 there were only 29 executions), and JoInT Legis. Audit \& REv. CoMm'n, Review of VIRGINIA'S SYSTEM OF CAPITAL PUNISHMENT 17 (2002) (listing 170 capital murder indictments and 64 capital prosecutions between 1995 and 1999), with VA. INDIGENT DEF. COMM'N, ANNUAL REPORT 13 (2013) (noting that there were only 14 new capital case assignments in 2013).

126. See States With and Without the Death Penalty, Death Penalty Info. CtR., http:// deathpenaltyinfo.org/states-and-without-death-penalty (last visited Feb. 27, 2015) [hereinafter States With and Without the Death Penalty]. 
comfortably before the American public. ${ }^{127}$ In a steady pace since Gary Dotson became the first DNA exoneree in 1989, the American people have been confronted with a regular diet of faulty convictions for cases typically involving rape and murder. ${ }^{128}$ As of today, there have been over 320 DNA exonerations nationally. ${ }^{129}$

With regard to death row exonerations, 150 people have had their death sentences vacated, twenty of whom were cleared through DNA evidence. ${ }^{130}$ Virginia alone has witnessed sixteen DNA exonerations. ${ }^{131}$ Strikingly, a recent empirical study by a prominent death penalty scholar asserts that there is a $4.1 \%$ error rate for those sentenced to death. ${ }^{132}$ The public and its elected officials are slowly becoming hesitant about a practice that no longer has the veneer of infallibility.

Other factors affecting the diminished support of the death penalty include heavy costs, international normative pressures, and changing demographics. ${ }^{133}$ The emergence of life without parole is also credited with ratcheting downward the public's support of this entrenched, controversial sanction. ${ }^{134}$ Whatever the mix, the death penalty is in a slow, but persistent decline. ${ }^{135}$ Six

127. See Innocence: List of Those Freed from Death Row, DeATH PENALTy InFo. CTR., http://www.deathpenaltyinfo.org/innocence-list-those-freed-death-row (last visited Feb. 27, 2015) (listing twenty exonerations since 1973 in which DNA played a significant role).

128. See History \& Accomplishments, MID-ATL. InNOCENCE PROJECT, http://www.exon erate.org/mission/historyaccomplishments/ (last visited Feb. 27, 2015).

129. DNA Exonerations Nationwide, INNOCENCE PROJECT, http://www.innocencepro ject.org/Content/DNA_Exonerations_Nationwide.php (last visited Feb. 27, 2015).

130. Id.; Pennsylvania Governor Announces Moratorium on Executions, DEATH PENALTY INFO. CTR., http://www.deathpenaltyinfo.org/node/6054 (last visited Feb. 27, 2015).

131. Eyewitness Memory Often Unreliable, RicH. Times-DisPaTch (July 26, 2014, 10:30

PM), http://www.richmond.com/news/state-regional/eyewitness-memory-often-unreliable/ article_dc653f7d-c93d-576c-b5bf-e7122970bdd3.html.

132. Samuel R. Gross et al., Rate of False Conviction of Criminal Defendants Who Are Sentenced to Death, 111 PROcEEDINGS NAT'L ACAD. SCI. 7230, 7234 (2014).

133. See Art Swift, Americans: "Eye for an Eye" Top Reason for Death Penalty, GaLluP (Oct. 23, 2014), http://www.gallup.com/poll/178799/americans-eye-eye-top-reason-deathpenalty.aspx (identifying cost as a basis for opposition to the death penalty); see also James Gibson \& Corinna Barrett Lain, Death Penalty Drugs and the International Moral Marketplace, 103 GEO. L.J.__ (forthcoming 2015) (discussing various factors which have had an impact on perception of the death penalty).

134. Gibson \& Lain, supra note 133 (stating the low rate of support for the death penalty where an alternative for life without parole is available).

135. Jeffrey M. Jones, Americans' Support for Death Penalty Stable, GalluP (Oct. 23, 2014), http://www.gallup.com/poll/178790/americans-support-death-penalty-stable.aspx. 

1 1989, the Ameri- diet of faulty connurder. ${ }^{128}$ As of tois nationally. ${ }^{129}$

J people have had hom were cleared witnessed sixteen pirical study by a there is a $4.1 \%$ erblic and its elected a practice that no

states have repealed the death penalty in the last eight years. ${ }^{136}$ Various reasons for repeal have been proffered by the leading public officials in these states, including cost and anxiety over executing the innocent. ${ }^{137}$

Notwithstanding why, the normative milieu here and now is different than it was when Strickler was tried and sentenced to death, a time when support for the death penalty was over $70 \%{ }^{138}$ Today, Strickler would have faced a community, prosecutor, and jury potentially more sensitive to wrongful convictions and the special status of the intellectually disabled. Also, these important institutional actors likely would have been more exposed to friends and family opposed to the death penalty. These factors matter even though they cannot be quantitatively measured. As criminal justice actors know deep in their bones, qualitative differences-sociopolitical, psychological, narrative, demographic, and others-affect trial outcomes. ${ }^{139}$

No doubt this changed climate would have impacted Strickler's trial. It is clear that policymakers, prosecutors, and the public,

or Death Penalty, GALLUP eye-eye-top-reason-deathdeath penalty); see also $d$ the International Moral arious factors which have support for the death pen-

136. States With and Without the Death Penalty, supra note 126.

137. See Jeremy W. Peters, Death Penalty Repealed in New Jersey, N.Y. TiMES (Dec. 17, 2007), http://www.nytimes.com/2007/12/17/nyregion/17cnd-jersey.html?_r=0 (citing "sanctity of life" as a basis for removal of the death penalty); Joe Sutton, Maryland Governor Signs Death Penalty Repeal, CNN (May 2, 2013, 2:53 PM), http://www.cnn.com/2013/ 05/02/us/maryland-death-penalty/ (citing lack of deterrent effect, cost, and "racial bias" as justifications for removing the death penalty); Christopher Wills, Illinois Gou. Pat Quinn Abolishes Death Penalty, Clears Death Row, WASH PoST. (Mar. 9, 2011, 8:17 PM), http:// www.washingtonpost.com/wp-dyn/content/article/2011/03/09/AR2011030900319.html (citing lack of certainty as a basis for abolishing death penalty); New Mexico Governor Repeals Death Penalty in State, CNN (Mar. 18, 2009, 11:06 PM), http://www.cnn.com/2009/CRIME /03/18/new.mexico.death.penalty/ (citing lack of confidence in the system as a basis for repeal of the death penalty); New York, DeATH PENALTY INFO. CTR., http://www.deathpenal tyinfo.org/new-york-1 (last visited Feb. 27, 2015) (discussing the history of the death penalty in New York and its abolition in 2007); No More Death Penalty in CT, NBC ConN. (Apr. 25, 2012, 7:22 PM), http://www.nbcconnecticut.com/news/local/No-More-Death-Penal ty-in-CT-148918245.html (citing "unworkability" as a basis for removal of death penalty).

138. See Jeffrey M. Jones, U.S. Death Penalty Support Lowest in More Than 40 Years, GALLUP (Oct. 29, 2013), http://www.gal lup.com/poll/165626/death-penalty-support-lowestyears.aspx; see also Jones, Americans' Support for Death Penalty Stable, supra note 135 ("Since 1937, support has been as low as $42 \%$ in 1966 and as high as $80 \%$ in 1994.").

139. See, e.g., Duren v. Missouri, 439 U.S. 357, 360 (1979) (holding that a prima facie constitutional violation can be proven if females are excluded from venire); Bidish J. Sarma, Challenges and Opportunities in Bringing the Lessons of Cultural Competence to Bear on Capital Jury Selection, 42 U. MEM. L. REV. 907, 912-13 (2012) (discussing the importance of humanizing a defendant to the jury through a cultural lens); cf. Edith Greene, Media Effects on Jurors, 14 LAW \& HUM. BEHAV. 439, 443-44 (1990) (discussing the potential effect of the media on jury decisions). 
even those who support the death penalty, bring a more cautious approach to the enterprise today. There is no reason to assume that Strickler's case would not have been meaningfully affected by the waning public support for the death penalty. He almost certainly would have been the beneficiary of the public's increased hesitancy on the death penalty.

\section{Creation of the Capital Defender Units: The Benefits of Intentional Investment for Capitally Charged Indigent Defendants}

Virginia was well-known nationally as a low performer in the delivery of indigent defense at the time of Strickler's capital trial. At the time, there were inadequate qualifications for courtappointed counsel. ${ }^{140} \mathrm{~A}$ patchwork of public defenders and lawyers from court-appointed lists provided indigent defense in capital cases. ${ }^{141}$ As of the year 2000, 97\% of death row inmates since 1977 in Virginia had court-appointed counsel. ${ }^{142}$

Strickler had two court-appointed counsel to represent him during his capital trial. ${ }^{143}$ One was a public defender and the other was drawn from the private bar. Undoubtedly, they were both under-resourced and had not received adequate training in this complex area of the law. In fact, the public defender had been deemed ineffective in a previous capital case. ${ }^{144}$

Even apart from the Brady issue the Court agreed to hear, Strickler's trial was pocked with infirmities. Any full examination of the trial would expose many of the operational problems of the death penalty. ${ }^{145}$ So often these problems are invisible to the pub-

140. See ACLU of VA., Broken Justice: The Death Penalty in Virginia 31 (2003) [hereinafter BROKEN JUSTICE], http://www.aclu.org/files/FilesPDFs/broken_ justice. pdf (indicating the recent improvement that the Virginia legislature has made in ensuring better quality lawyers for capital cases).

141. See Adam M. Gershowitz, Raise the Proof: A Default Rule for Indigent Defense, 40 CONN. L. REV. 85, 96-97 (2007) (referring to the poor quality of attorneys available for court-appointed lists).

142. BROKEN JUSTICE, supra note 140, at 28.

143. See Strickler v. Greene, 527 U.S. 263, 277 (1998) ("In December 1991, the Augusta County Circuit Court appointed new counsel to represent petitioner in state habeas corpus proceedings."); see Case Note, Strickler v. Pruett, Nos. 97-29, 97-30, 1998 WL 340420, (4th Cir. June 17, 1998), 11 CAP. DEF. J. 145, 147 n.38 (1998).

144. UNEQUAL, UNFAIR AND IRREVERSIBLE, supra note 125, at 18.

145. See Initial Petition for Writ of Habeas Corpus, Strickler v. Netherland, No. 

ningfully affected nalty. He almost the public's in-

\section{Benefits of \\ Indigent}

performer in the ler's capital trial. ations for courtders and lawyers efense in capital mates since 1977

o represent him ider and the oth, they were both training in this fender had been

agreed to hear, full examination problems of the sible to the pub-

lic at large and even to some actors within the system, as with the Stoltzfus materials. The mechanical problems that unfold at the sub-cellular level of criminal trials include the legal maneuvers, tactical omissions, and resource constraints that usually dictate the fate of capital defendants. ${ }^{146}$ Unsurprisingly, Strickler's trial had these problems as well.

How might Strickler's capital trial have been different under Virginia's current capital defender units? What quality and resource differences would be at play?

In 2002, the Commonwealth of Virginia created four regional capital defender units. ${ }^{147}$ These units were designed so that capital-eligible defendants would receive more uniform, expert defense services while facing the threat of losing their lives at the state's behest. ${ }^{148}$ This was a major development in the history of the delivery of indigent defense services for the state. Virginia paid its court-appointed capital defense counsel less than any other state prior to switching to the capital defender unit system. ${ }^{149}$

In today's capital litigation environment, Strickler would have had a highly trained capital defender, along with a well-trained appointed co-counsel, whose sole responsibility would have been to meet the needs of their capitally charged defendants. ${ }^{150}$ They almost certainly would have had direct access to a fact investigator and a mitigation specialist, both of whom would have been also specially trained and singularly assigned for this work. ${ }^{151}$ In

3:95CV924 (E.D. Va. filed Mar. 7, 1996) (citing eighteen claims and seventeen subclaims of error establishing grounds for unlawful detention).

146. See Stephen B. Bright, Death By Lottery-Procedural Bar of Constitutional Claims in Capital Cases Due to Inadequate Representation of Indigent Defendants, 92 W. VA. L. REV. 679, 685 (1990) (discussing how the lack of appropriate standards for inadequate counsel means death sentences are the result of the "luck of the lawyers [the defendants] draw").

147. See VA. CodE ANN. §§ 19.2-163.2, -163.7 (Cum. Supp. 2002); Va. Code Ann. § 19.2163.2 (Michie Supp. 2002) Va. Code Ann. § 19.2-163.7 (Michie Supp. 2002), 15 CAP. DEF. J. 283, 283 (2002) [hereinafter Va. Code Recap].

148. Va. Code Recap, supra note 147, at 284-85.

149. SPANGEnberg GrP., Am. BAR Ass'N, A Comprehensive REview of InDigent DEFENSE IN VIRGINIA 7 (2004), available at http://www.americanbar.org/content/dam/aba/ migrated/legalservices/downloads/sclaid/indigentdefense/va_report2004.authcheckdam. pdf.

150. See VA. CodE ANN. §§ 19.2-163.7-163.8 (Repl. Vol. 2008).

151. See Am. Bar Ass'n, Evaluating FaIRnEss and ACCURACY in State Death Penalty Systems: The Virginia DeAth Penalty Assessment Report iv (2013) [herein- 
this essay's time machine, the fact investigator may well have been able to unearth Stoltzfus's inconsistent statements, a development that would have changed the complexion of plea bargaining, the trial, and sentencing. Undoubtedly, the mitigation specialist would have systematically delved into Strickler's educational, family, medical, and social background. This, in turn, would have unquestionably led to a cohesive, compelling narrative at the sentencing portion of Strickler's trial.

With regard to long-vocalized aspirational goals around parity and a level playing field between defense and prosecution in the indigent defendant arena, the prosecutor would have known from the outset that he would be dealing with a formidably trained and experienced defense team. This alone could have led to plea negotiation benefits for Strickler. ${ }^{152}$ In toto, these enhancements in defense resources would today have an enormous effect on the quality, direction, and strength of Strickler's defense.

Beginning with the reinstatement of the death penalty in Virginia in 1976, and including up until the creation of the capital defender units in 2004, 84\% of capital cases that went to trial resulted in a death sentence. ${ }^{153}$ Between 2005 and 2011, only $47 \%$ of the same type of cases resulted in death sentences. ${ }^{154}$ These units are widely viewed as repositories for subject matter expertise and dedicated professionals who infuse the process with this specialized knowledge. ${ }^{155}$ No doubt Strickler would have been better off in the expert hands of these legal advocates who now have the structural and improved, if not sufficient, fiscal infrastructure to support their democratically critical mission. The passage of time tells us that the existence of the capital defender units have substantially changed for the better how indigent capital defense is delivered.

after EVALUATING FAIRNESS], available at www.americanbar.org/content/dam/aba/admin istrative/death_penalty_moratorium/va_complete_report.authcheckdam.pdf.

152. See Douglass, supra note 124, at

153. Evaluating FaIRNESS, supra note 151, at 142.

154. Id.

155. See Va. Code Recap, supra note 147, at 284.

156. See MALCOLM

157. Gregg v. Geor

158. See Steiker \& 
may well have ements, a develof plea bargainmitigation spento Strickler's round. This, in sive, compelling rial.

S around parity osecution in the ave known from ibly trained and ed to plea negoncements in deect on the qual-

penalty in Vir$n$ of the capital went to trial re11 , only $47 \%$ of s. ${ }^{154}$ These units r expertise and ith this specialbeen better off now have the frastructure to passage of time units have subpital defense is

\section{IMPRESSIONS AND IMAGININGS}

This case study about one man's capital trial and its narrative is a critique of how arbitrariness afflicts the death penalty in a strictly temporal sense. The cultural observer Malcolm Gladwell contends that so much of extraordinary success for athletes or entrepreneurs in life can depend on the year and month they were born. ${ }^{156}$ Unlike in the happy Gladwellian sense concerning superachievers, in the death penalty arena, the kismet of time often controls which defendants live or die at the state's direction. Although the historicity of any case is quite obviously significant in a legal system that evolves over time through case law and statutory changes, Strickler's trial would be markedly different today. This is of greater moral consequence to a democracy than changes made to other areas of the law. To borrow a famous phrase, "Death is different."157

Watershed constitutional rulings such as Atkins remind us that we really do not have a moral hold on this mighty power of the state to take human life. Rulings of this sort seem not to announce glorious new terrain, but rather they seem to be shameful admissions of what we already knew or deeply suspected. The increasing ways in which the public is either rejecting the death penalty outright, wanting to limit its scope, or hoping that the delivery of defense services is strengthened to avert the retributive nightmare of executing the innocent make our "moment in time" death penalty system especially difficult to support in a modern society dedicated to notions of human dignity and transparency.

As the modern era of the death penalty nears its fortieth birthday, the death penalty brings to mind the prickly adage that by forty you have the face you deserve. The face of the death penalty is worn and haggard. Its return trips for cosmetic nips and tucks are beneath the dignity of the world's major democracy. Our wish to rationalize the death penalty's operation through myriad legislative and judicial interventions is a failed undertaking. ${ }^{158}$

156. See Malcolm GladWeld, OUtliers: The Story OF Success 22-23 (2008).

157. Gregg v. Georgia, 428 U.S. 153, 188 (1976).

158. See Steiker \& Steiker, supra note 97 , at $211-15$. 
Most importantly, the backward glance of this essay illustrates how the temporal space of doctrinal developments, public policy, and societal mood is a major arbitrary factor in death penalty outcomes. ${ }^{159}$ These sociopolitical elements are by their very nature immutably time-bound and thus they burden the death penalty, and us-as the citizens in whose names the penalty is imposedwith another reminder of its problematic, unsteady administration. Contrary to the hopes of reformers and retentionists, time has not healed what ails the death penalty. Instead, time exposes its decaying moral and operational foundation. If the past is indeed prologue, the future's interventions, short of abolition, are likely to be no different. Temporal arbitrariness has been the modern death penalty's one and only constant.

159. Cf. JoInT Legis. Audit AND Rev. Comm'N, supra note 125, at 29 (demonstrating the importance of locality in capital crime outcomes).

MAKING SUR REPAIRING “ NARROWING

Can we fix t] want to? Or sho er, as so many tions that many 2014 as botche multiple innoce for years. ${ }^{2}$ Desp and state depar stitutional ques sues, including proportionately

1. CAP. PUNISHI INTERNATIONAL INTEI idp_report.pdf.

2. See, e.g., Mich http://www.wfla.com/s (last updated Sept. 18 Slaying, OHIO.COM $(\mathrm{N}$ ge-dismisses-two-men Post-Furman Botched deathpenaltyinfo.org/s

3. Samuel R. Gr Sentenced to Death, 11 4. Samuel R. Gr tion: Why We Know STUD. 927, 942 (20 EXONERATIONS, EXON between 1977 and 200 exonerations occurred 